\title{
Ellipsis
}

2014

\section{Smoking Outside with My Cat on Sunday Morning}

Andrea Panzeca

University of New Orleans

Follow this and additional works at: https://scholarworks.uno.edu/ellipsis

Part of the Poetry Commons

\section{Recommended Citation}

Panzeca, Andrea (2014) "Smoking Outside with My Cat on Sunday Morning," Ellipsis: Vol. 41 , Article 17. DOI: https://doi.org/10.46428/ejail.41.17

Available at: https://scholarworks.uno.edu/ellipsis/vol41/iss1/17

This Poetry is brought to you for free and open access by the Department of English and Foreign Languages at ScholarWorks@UNO. It has been accepted for inclusion in Ellipsis by an authorized editor of ScholarWorks@UNO. For more information, please contact scholarworks@uno.edu. 


\title{
Smoking Outside with My Cat on Sunday Morning
}

\author{
Andrea Panzeca
}

On my back porch, a concrete slab surrounded by a dirt and pebble driveway,

I arrange a beach chair to get the most sunlight; but under trees I have to trade

- my torso in the shade - to tan my face and feet, propped on a plant pot. I inhale

with my eyes closed, inside the lids bright red, like a baby trying to go back in.

I think about Ben Affleck, how his wife was good in 13 Going on 30, which Megan

recommended, and come up with my own private anagram-Panacea Zander.

Now Mike's awake. The door's open and I hear as he washes dishes and listens

to Five Blind Boys from Alabama. I think I feel the Holy Spirit. Pinky rubs

her whiskers on a flimsy tree-she's going into heat.

My left eye won't stop crying.

Mike joins me from inside. Have you eaten yet today, my little angel trumpet? 